\title{
ANALISIS PENERAPAN SISTEM MANAJEMEN KESELAMATAN DAN KESEHATAN KERJA (SMK3)
}

\author{
Herlinawati*Anang Sofyan Zulfikar**
}

\begin{abstract}
ABSTRAK
Sistem Manajemen Keselamatan dan Kesehatan Kerja (SMK3) adalah bagian dari sistem manajemen perusahaan secara keseluruhan dalam rangka pengendalian risiko yang berkaitan dengan kegiatan kerja guna terciptanya tempat kerja yang aman, efisien dan produktif. Dikeluarkan PP RI Nomor 50 Tahun 2012 tentang Penerapan Sistem Manajeman Keselamatan dan Kesehatan Kerja, pasal 5 UU tersebut mewajibkan setiap perusahaan menerapkan SMK3 di perusahaanya, berlaku bagi perusahaan yang mempekerjakan pekerja/buruh paling sedikit 100 (seratus) orang atau mempunyai tingkat potensi bahaya tinggi. Tujuan penelitian ini adalah untuk mengetahui analisis penerapan Sitem Manajemen Keselamatan dan Kesehatan Kerja (SMK3) di PT Japfa Comfeed Indonesia Tbk Unit Cirebon Tahun 2016. Jenis penelitian yang digunakan adalah kualitatif dengan metode penelitian studi kasus, teknik pengambilan sampel menggunakan purposive sampling dan Snowball Sampling dengan sampel yaitu Kepala Unit, Kepala seksi K3LH, Ka.Sub.Dept. Teknik, Operator IPAL dan Personil Security, pengumpulan data dengan cara wawancara mendalam sedangkan instrumen yang digunakan berupa kuesioner, lembar chek list serta dokumentasi dan recorder. Hasil penelitian ini adalah secara umum penerapan SMK3 di PT Japfa Comfeed Indonesia Tbk Unit Cirebon hampir semua kriteria terpenuhi namun ada beberapa kriteria yang belum terpenuhi. Penerapan penetapan kebijakan K3, penerapan perencanaan K3, penerapan pelaksanaan rencana K3 hampir semua kriteria terpenuhi namun ada beberapa kriteria yang belum terpenuhi dan pemantauan dan evaluasi kinerja K3 sudah terpenuhi semua.
\end{abstract}

Kata kunci : : Analisis, Penerapan SMK3

\begin{abstract}
Occupational Health and Safety Management System are part of corporate management system as a whole in order to operation run the risk that gets bearing with utilised job activity most composes safe workshop it, efficient and productive. Issued by PP RI Number 50 Years 2012 about Manajeman's System Implement safety and job healths, section $5 \mathrm{UU}$ that makes compulsory one each company apply SMK3 at company, apply to firm that employ employ / least labour 100 (a hundred) person or has tall lurching potency zoom. To the effect this research is subject to be knowanalisis is Sitem's implement Occupational Health and Safety Management System at PT Japfa Comfeed Indonesian Tbk Unit Cirebon Year 2016 .Observational type that is utilized is kualitatif by methodics case study research, its sample utilizes purposive is sampling and Snowball Sampling which is Section Head K3LH, Ka.Sub.Dept is Tech, WWTP Operator and Security Personnel data collection by way of depth interviews while the instrument used a questionnaire, sheet chekc list documentation and recorder. The results of this study are in general application SMK3 in PT Japfa Comfeed Indonesian Tbk Unit Cirebon almost all the criteria are met, but there are several criteria that have not been fulfilled. Implementation of the policy-setting K3, K3 planning application, the application of the implementation plan K3 almost all the criteria are met, but there are several criteria that have not been fulfilled, and the monitoring and evaluation of the performance of the $\mathrm{K} 3$ has fulfilled all.
\end{abstract}

Key words : : Analisis, The Application Of SMK3

\footnotetext{
* Staf Pengajar PSKM STIKes Cirebon

** Alumni PSKM STIKes Cirebon Lulus Tahun 2016
} 


\section{PENDAHULUAN}

Data dari International Labour Organization (ILO) tahun 2014, 1 pekerja di dunia meninggal setiap 15 detik karena kecelakaan kerja dan 337 juta pekerja mengalami sakit akibat kerja. ILO mencatat angka kematian dikarenakan kecelakaan dan penyakit akibat kerja (PAK) sebanyak 2,3 juta ksus setiap tahun. ${ }^{1}$

Menurut Badan Penyelenggara Jaminan Sosial (BPJS) Ketenagakerjaan Indonesia mendata selama 2014 jumlah peserta yang mengalami kecelakaan kerja sebanyak 129.911 orang. Dimana 69,59\% kecelakaan terjadi di dalam perusahaan saat bekerja, 10,26\% kecelakaan terjadi di luar perusahaan, dan sekitar $20,15 \%$ pekerja mengalami kecelakaan lalu lintas. $^{2}$

Berdasarkan data BPJS Ketenagakerjaan, jumlah kecelakaan kerja di Provinsi Jawa Barat sepanjang tahun 2014 berjumlah 3.751 kasus dengan besaran klaim mencapai Rp 16,77 miliar rupiah. ${ }^{3}$

Dinas Tenaga Kerja dan Transmigrasi (Disnakertrans) Kabupaten Cirebon menyebutkan, untuk di Kabupaten Cirebon pada tahun 2014 berdasarkan data laporan kecelakaan kerja terjadi kasus kecelakaan kerja dengan korban meninggal 11 orang, luka ringan 185 orang dan luka berat 10 orang. ${ }^{4}$ Kondisi ini disebabkan karena masih kurangnya kesadaran dan pemahaman aspek K3 sebagai salah satu unsur untuk meningkatkan daya saing. ${ }^{5}$

Menurut Suma'mur, 80-85\% kecelakaan disebabkan oleh kelalaian (unsafe human acts) dan kesalahan manusia (human error). Kecelakaan dan kesalahan manusia tersebut meliputi faktor usia, jenis kelamin, pengalaman kerja dan pendidikan. Kesalahan akan meningkat ketika pekerja mengalami stress pada beban pekerjaan yang tidak normal atau ketika kapasitas kerja menurun akibat kelelahan. ${ }^{6}$

Kualitas pekerja mempunyai korelasi yang erat dengan kecelakaan kerja sedangkan kecelakaan kerja erat kaitannya dengan produktivitas sehingga program SMK3 sangat mempengaruhi program pengembangan sumber daya manusia. ${ }^{7}$

SMK3 dapat memberikan perlindungan bagi masyarakat suatau perusahaan agar terhindar dari bahaya pengotoran bahan-bahan industrialisasi, dan perlindungan bagi masyarakat luas dari bahaya-bahaya yang mungkin ditimbulkan oleh produk-produk industri. $^{7}$

Salah satu upaya pemerintah untuk mengurangi kecelakaan kerja adalah dengan mengeluarkan Undang-Undang RI No. 13 Tahun 2003 tentang Ketenagakerjaan. Pasal 87 UU tersebut mewajibkan setiap perusahaan menerapkan SMK3 sebagai bagian dari Manajemen perusahaan, dan bagi yang tidak menerapkannya akan diberi sanksi. Pemerintah juga mengeluarkan PERMENAKER No.05/MEN/1996 tentang pedoman penerapan SMK3 dan parameter audit SMK3. Selain itu, telah dikeluarkan Peraturan Pemerintah (PP) Nomor 50 tahun 2012 tentang SMK3. PP tersebut merupakan peraturan pelaksanaan dari pasal $87 \mathrm{UU}$ No. 13 Tahun 2003 tentang Ketenagakerjaan. PP Nomor 50 tahun 2012 menyatakan perusahaan yang memiliki karyawan lebih dari seratus atau kurang dari seratus tetapi memliki potensi bahaya kecelakaan kerja cukup tinggi, maka wajib menerapkan SMK3. ${ }^{8}$

Dari total 1.200 perusahaan yang berada di wilayah Cirebon, baru $60 \%$ perusahaan yang sudah di daftarkan sebagai kepesertaan BPJS Ketenagakerjaan dan BPJS Kesehatan. ${ }^{11}$ PT Japfa Comfeed Indonesia Tbk Unit Cirebon telah menerapkan Sistem Manajemen Keselamatan dan Kesehatan Kerja (SMK3) disemua ruang lingkup unit usahanya, berdasarkan Peraturan Pemerintah Republik Indonesia No. 50 tahun 2012. ${ }^{9}$

Dalam penelitian lainnya yang dilakukan Rahimah Azmi D pada tahun 2008 yaang berjudul Penerapan Sistem Manajemen Keselamatan dan Kesehatan Kerja (SMK3) oleh P2K3 di PT. Wijaya Karya Beton Medan. Sistem Manajemen Keselamatan dan Kesehatan Kerja (SMK3) secara keseluruhan didokumentasikan dalam pedoman SMK3 yang disusun 
secara rinci. Uraian penerapan SMK3 diintegrasikan dengan prosedur mutu sebagai satu kesatuan dengan Sistem Manajemen Mutu ISO 9001:2000, sedangkan penerapan SMK3 secara praktis dilapangan, proyek maupun di pabrik produk beton disusun dalam instruksi kerja K3. Sejak awal penerapan SMK3 terus dilakukan perbaikan dalam hal identifikasi bahaya dan sering menjadi temuan dalam audit SMK3 internal maupun eksternal. ${ }^{10}$

Perencanaan K3 di PT Japfa Comfeed Indonesia Tbk Unit Cirebon mempertimbangkan hasil penelaahan awal, identifikasi potensi bahaya, penilaian dan pengendalian risiko, peraturan perundang-undangan dan persyaratan lainnya serta sumber daya yang dimiliki. ${ }^{11}$

Pelaksanaan rencana K3 di PT Japfa Comfeed Indonesia Tbk Unit Cirebon didukung oleh SDM dibidang K3, sarana dan prasarana. Direksi PT Japfa Comfeed Indonesia Tbk Unit Cirebon membentuk Panitia Pembina Keselamatan dan Kesehatan Kerja (P2K3). Ketua P2K3 adalah seorang yang ditunjuk oleh Head of Unit, sekertaris P2K3 adalah Ahli K3 Umum atau HSE Officer dan Anggota P2K3 merupakan wakil dari pekerja setiap bagian. ${ }^{11}$

Pemantauan dan Evaluasi Kinerja K3 di PT Japfa Comfeed Indonesia Tbk Unit Cirebon melalui pemeriksaan, pengujian, pengukur dan audit internal SMK3 dilakukan oleh SDM yang kompeten. ${ }^{11}$ Berdasarkan hasil laporan audit internal SMK3 yang telah dilaksanakan oleh PT Japfa Comfeed Indonesia Tbk Unit Cirebon, dari 166 kriteria penilaian SMK3 terdapat temuan 53 kriteria yang tidak sesuai dalam penerapan SMK3 berdasarkan PP No. 50 Tahun $2012 .{ }^{12}$

Tujuan penelitian untuk mengetahui Analisis Penerapan Sistem Manajemen Keselamatan dan Kesehatan Kerja (SMK3) di PT Japfa Comfeed Indonesia Tbk Unit Cirebon Tahun 2016.

\section{METODE PENELITIAN}

Jenis penelitian yang digunakan dalam penelitian ini adalah metode kualitatif. ${ }^{2} J e n i s$ penelitian kualitatif ini menggunakan desain penelitian studi kasus. Studi kasus dilakukan dengan cara meneliti suatu permasalahan melalui suatu kasus yang terdiri dari unit tunggal. Penggunaan jenis penelitian kualitatif dengan desain studi kasus ini adalah untuk menganalisis Penerapan Sistem Manajemen Keselamatan dan Kesehatan Kerja (SMK3) di PT. Japfa Comfeed Indonesia Tbk unit Cirebon tahun 2016. ${ }^{13}$

Adapun fokus dari penelitian ini adalah Penerapan Sistem Manajemen Keselamatan dan Kesehatan Kerja (SMK3) dan sub fokus dalam penelitian ini adalah penetapan kebijakan $\mathrm{K} 3$, perencanaan K3, pelaksanaan rencana K3, pemantauan dan evaluasi kinerja K3.

Teknik sampling dalam penelitian ini yaitu Purposive Sampling adalah teknik pengambilan sampel sumber data dengan pertimbangan tertentu yang dianggap orang tersebut paling tahu apa yang kita harapkan sehingga akan memudahkan peneliti menjelajahi objek/situasi sosial yang diamati. Selain itu menggunakan teknik sampling Snowball Sampling adalah teknik pengambilan sampel sumber data, yamg pada awalnya jumlahnya sedikit, lama-lama menjadi besar. ${ }^{14}$

Instrumen yang digunakan dalam penelitian ini dengan pedoman wawancara/kuesioner, lembar check list, buku catatan, recorder serta dokumentasi. ${ }^{15}$ Dalam penelitian kualitatif instrumen utamanya adalah peneliti sendiri, namun selanjutnya setelah fokus penelitian menjadi jelas, maka kemungkinan akan dikembangkan instrument penelitian sederhana, yang diharapkan dapat melengkapi data dan membandingkan dengan data yang telah dilakukan melalui observasi dan wawancara. ${ }^{14}$

Penelitian ini menggunakan teknik Triangulasi yaitu teknik pengumpulan data yang bersifat menggabungkan dari teknik pengambilan data diantaranya wawancara mendalam (in depth interview), observasi langsung (direct observation), dokumentasi dan pengisian lembar 
check list. ${ }^{14}$ Data yang dikumpulkan dalam penelitian ini dalam memperoleh informasi menggunakan data primer dan sekunder. Data Primer diperoleh peneliti dengan cara melakukan wawancara mendalam (indepth innterview) dengan menggunakan lembar pertanyaan yang tersusun kepada informan inti yaitu Kepala Unit, Kepala seksi K3LH dan Personil Security meliputi informasi tentang Penerapan Sistem Manajemen Keselamatan dan Kesehatan Kerja (SMK3) di PT. Japfa Comfeed Indonesia Tbk Unit Cirebon. Data sekunder diperoleh dari telaah dokumen-dokumen dan arsip perusahaan yang terkait dengan Penerapan Sistem Manajemen Keselamatan dan Kesehan Kerja (SMK3) di PT. Japfa Comfeed Indonesia Tbk Unit Cirebon untuk mengkaji ulang kebenaran informasi yang didapat dari hasil wawancara mendalam (in depth interview).

Analisis data dilakukan secara kualitatif untuk mendapatkan informasi mendalam tentang Penerapan Sistem Manajemen Keselamatan Dan Kesehatan Kerja (SMK3) dengan menggunakan matriks yang berisi data ringkasan hasil wawancara mendalam dari hasil transkrip wawancara.

\section{HASIL PENELITIAN}

\section{Penetapan kebijakan K3}

Dalam penyusunan kebijakan K3 di PT Japfa Comfeed Indonesia Tbk Unit Cirebon, perusahaan melakukan tinjauan awal kondisi K3 yang meliputi identifikasi potensi bahaya, penilaian dan pengendalian risiko di seluruh area perusahaan.

Penyusunan kebijakan K3 PT Japfa Comfeed Indonesia Tbk Unit Cirebon dilakukan melalui proses konsultasi antara pengurus dan wakil pekerja/buruh dengan pernyataan tertulis yang ditandatangan oleh Head of Unit yang memuat komitmen dan tekad melaksanakan $\mathrm{K} 3$, kerangka dan program kerja yang mencakup kegiatan perusahaan secara menyeluruh yang bersifat umum atau profesional.

PT Japfa Comfeed Indonesia Tbk Unit Cirebon menetapkan personil yang mempunyai tanggung jawab, wewenang dan kewajiban secara keseluruhan yang meliputi struktur organisasi, perencanaan, pelaksanaan, prosedur proses dan sumber daya yang dibutuhkan bagi pengembangan penerapan dan pencapaian pengkajian serta pemeliharaan kebijakan K3 yang ditinjau secara berkala dan di evaluasi guna terciptanya tempat kerja yang aman, efektif dan produktif.

\section{Perencanaan K3}

1. Rencana Strategi K3

Penyusunan rencana K3 PT Japfa Comfeed Indonesia Tbk Unit Cirebon berdasarkan hasil penelaahan awal yang diidentifikasi dan dievaluasi untuk memastikan tujuan dan sasaran K3 sesuai dengan bahaya potensial dan risiko dimana PT Japfa Comfeed Indonesia Tbk Unit Cirebon memiliki pengaruh. Tinjauan bahaya potensial dan risiko dilaksanakan dua kali dalam setahun atau bila terjadi perubahan proses, dan atau perubahan perundangundangan yang berarti, atau muncul perkembangan unit usaha yang baru. Koordinator tim investigasi dan rekomendasi bertanggung jawab untuk membuat, menyusun dan memeriksa daftar identifikasi bahaya potensial dan evaluasi risiko serta daftar risiko penting K3.

2. Perundang-undangan dan Persyaratan Lainnya

Perundang-undangan dan persyaratan lainnya yang dapat diterapkan di PT Japfa Comfeed Indonesia Tbk Unit Cirebon diidentifikasi dan ditinjau ulang pemenuhannya oleh Manajemen Representatif K3 untuk memastikan komitmen dalam kebijakan K3 terpenuhi. Manajemen PT Japfa Comfeed Indonesia Tbk Unit Cirebon menentukan persyaratan K3 lainnya, yang secara umum diterjemahkan sebagai standar atau kode industri, persyaratan K3 dari klien, peraturan K3 internal PT Japfa Comfeed Indonesia Tbk Unit Cirebon untuk 
diterapkan dalam konteks sistem manajemen K3 perusahaan. Persyaratan perundangundangan akan ditinjau ulang dalam rangka tinjauan ulang Identifikasi Potensial dan Evaluasi Risiko dalam menanggapi adanya perubahan perundang-undangan atau perubahan proses, atau perubahan perundang-undangan dan pekerjaan atau proyek dengan bidang yang baru.

3. Tujuan dan Sasaran K3

PT Japfa Comfeed Indonesia Tbk Unit Cirebon membuat tujan dan sasaran K3 dengan memperhatikan hasil identifikasi bahaya potensial dan evaluasi risiko, peraturan perundang-undangan dengan memperhatikan faktor biaya, teknologi dan sumber daya manusia. Manajemen Representatif dan masing-masing Kepala Departemen bertanggung jawab membuat dan menyusun tujuan dan sasaran K3. Head of Unit mengesahkan daftar tujuan dan sasaran K3. Fungsi terkait bertanggung jawab untuk membantu pelaksanaan pencapaian tujuan dan sasaran. Manajer terkait bertanggung jawab untuk memeriksa dan mengkaji ulang tujuan dan sasaran K3.

4. Program Manajemen K3

Program Manajemen K3 merupakan penerjemahan dari tujuan dan sasaran K3 yang berisi perencanaan implementasi, personel yang bertanggung jawab. Setiap Departemen dibantu Manajemen Representatif K3 menyusun Program Manajemen K3. Head of Unit mengesahkan Program Manajemen K3. Program Manajemen K3 dilaksanakan oleh setiap Departemen terkait dan tingkat pencapaiannya akan dijadikan agenda dalam Tinjauan Manajemen. Manajer terkait bertanggung jawab untuk memeriksa dan mengkaji program manajemen K3 dan melaporkan kemajuan dari program manajemen K3 secara periodik kepada Manajemen Representatif K3.

\section{Pelaksanaan rencana K3}

Pelaksanaan rencana K3 dilaksanakan PT Japfa Comfeed Indonesia Tbk Unit Cirebon dengan:

1. Pengadaan Sumber Daya manusia (SDM)

Prosedur pengadaan SDM dengan membuat prosedur pengadaan secara efektif dengan SDM yang mempunyai sertifikat K3 seperti sertifikat ahli K3 umum dan auditor SMK3.

2. Komunikasi K3

Kebijakan K3 dan seluruh prosedur, instruksi kerja dikomunikasikan ke pekerja melalui pelatihan, papan pengumuman $\mathrm{K} 3$ dan rapat pengurus $\mathrm{P} 2 \mathrm{~K} 3$ yang minimal dilakukan satu kali setiap bulan. Manajemen Representatif K3 bertanggung jawab untuk menanggapi komunikasi internal dan eksternal. Saat persyaratan K3 mempengaruhi jasa dan atau produk yang disediakan subkontraktor dan telah diidentifikasi adanya potensi bahaya dan evaluasi risiko, maka komunikasi akan dilakukan dengan pihak subkontraktor dalam proses pengadaan barang dan jasa serta label, peraturan K3, dan lain-lain. Konsultasi antara pekerja dan manajemen dilakukan dalam rapat pengurus rutin P2K3. Kinerja K3 PT Japfa Comfeed Indonesia Tbk Unit Cirebon akan dimasukan dalam laporan kinerja PT Japfa Comfeed Indonesia Tbk Unit Cirebon.

3. Tanggung Jawab dan Tanggung Gugat

Head of Unit PT Japfa Comfeed Indonesia Tbk Unit Cirebon menunjuk seseorang sebagai Manajemen Representatif K3 yang mempunyai peran, tanggung jawab dan wewenang untuk, memastikan persyaratan SMK3 dibuat, diterapkan dan dipelihara sesuai standar PP RI No. 50 tahun 2012 serta, melaporkan unjuk kerja SMK3 kepada Direksi sebagai wakil dari PT Japfa Comfeed Indonesia Tbk Unit Cirebon dengan pihak eksternal yang berkaitan dengan K3.

4. Pelatihan dan Kompetensi Kerja 
PT Japfa Comfeed Indonesia Tbk Unit Cirebon menyusun dan memelihara prosedur pelatihan yang meliputi identifikasi kebutuhan pelatihan yang dibutuhkan pekerja. Pelatihan dapat dilaksanakan oleh internal PT Japfa Comfeed Indonesia Tbk Unit Cirebon atau badan eksternal. Semua pekerja yang dapat menimbulkan risiko penting memperoleh pelatihan yang memadai. Hanya pekerja yang mempunyai ijin dan kompetensi yang dipersyaratkan untuk dapat mengikuti tugas tersebut. Seluruh karyawan PT Japfa Comfeed Indonesia Tbk Unit Cirebon akan dilatih mengenai kepedulian terhadap SMK3. Bila dirasa perlu, maka akan dilakukan pelatihan penyegaran (refresh) untuk memelihara kepedulian terhadap K3. Catatan K3 dipelihara dan riwayat pelatihan pekerja selalu diperbarui.

5. Sistem Kerja

1) Organisasi/Unit yang bertanggung jawab dibidang $\mathrm{K} 3$

Direksi PT Japfa Comfeed Indonesia Tbk Unit Cirebon membentuk Panitia Pembina Keselamatan dan Kesehatan Kerja (P2K3). Ketua P2K3 adalah seseorang yang ditunjuk oleh Head of Unit, Sekretaris P2K3 adalah Ahli K3 Umum atau HSE Officer dan Anggota P2K3 merupakan wakil dari pekerja dari setiap bagian,

2) Prosedur operasi/kerja, informasi dan pelaporan

PT Japfa Comfeed Indonesia Tbk Unit Cirebon membuat dan memelihara prosedur pengendalian operasi terhadap bahaya potensial yang memiliki risiko penting. Setiap manajer, supervisor bertanggung jawab terhadap pelaksanaan prosedur pengendalian operasi. Pengendalian risiko yang dilaksanakan ditetapkan berdasarkan pada hirarki pengendalian. Penempatan pekerja untuk suatu pekerjaan memperhatikan persyaratan perijinan, kompetensi, kesehatan, identifikasi bahaya potensial dan evaluasi risiko.

PT Japfa Comfeed Indonesia Tbk Unit Cirebon memberlakukan sistem ijin kerja dan ijin masuk pada pekerja dan daerah-daerah yang teridentifikasi berdasarkan hasil identifikasi bahaya potensial dan evaluasi risiko. Tempat dengan ijin masuk dibuat pengendalian seperti pemberian tanda larangan dan membuat pagar.

PT Japfa Comfeed Indonesia Tbk Unit Cirebon menyediakan alat pelindung diri (APD) untuk seluruh pekerja yang membutuhkan sesuai dengan tugas dan bahaya potensial yang teridentifikasi. Pemeliharaan APD merupakan tanggung jawab dari pekerja. Seluruh APD dibuat dalam menilai tempat kerja untuk menentukan jika terdapat bahaya potensial atau yang akan muncul, yang memerlukan penggunaan APD. Pemeliharaan APD dikomunikasikan kepada pekerja yang terkena paparan. APD yang rusak atau tidak efektif dilarang digunakan. Pekerja dapat meminta penggantian APD kepada supervisornya.

Berdasarkan identifikasi bahaya potensial dan evaluasi risiko, pemantauan dan pengukuran, setiap ddaerah yang memiliki risiko penting diberi tanda peringatan K3 sesuai standar yang berlaku. PT Japfa Comfeed Indonesia Tbk Unit Cirebon menyediakan layanan yang sesuai dengan standar yang berlaku untuk bekerja.

Untuk mencegah pencemaran lingkungan, Team Lingkungan Hidup melakukan pengukuran dan pengujian NAB, Air Limbah, Kualitas Air Minum dan Air Bawah

Tanah. Sedangkan Team HAZOP dalam selang waktu terencana melakukan pengujian Bejana Tekanan, Kelayakan Boiler, Kelayakan Alat Angkat dan Angkut (Lift \& Forklift) serta pemeriksaan APD, Alat Pemadam Api Ringan (APAR) dan isi kotak P3K.

3) Pengendalian Dokumen K3

PT Japfa Comfeed Indonesia Tbk Unit Cirebon melakukan pengendalian dokumen SMK3 yang meliputi manual SMK3, Prosedur, Instruksi Kerja untuk menjamin bahwa :

(1) Dokumen ditempatkan pada lokasi yang membutuhkan dan ditentukan

(2) Dokumen dikaji secara berkala 
(3) Hanya dokumen terbaru yang tersedia diseluruh lokasi yang penting

(4) Dokumen kadaluarsa segera ditarik atau dimusnahkan dan master copy-nya disimpan sebagai catatan sejarah perubahan dokumen.

Direksi PT Japfa Comfeed Indonesia Tbk Unit Cirebon bertanggung jawab untuk mengesahkan Manual SMK3. Manajemen Representatif bertanggung jawab untuk mengesahkan prosedur, instruksi kerja dan Form K3.

Masing-masing manajer bertanggung jawab untuk membuat dan mengusulkan pengesahan prosedur, Instruksi Kerja dan Form K3 kepada Manajemen Representatif K3. Prosedur K3 dapat diubah berdasarkan kebutuhan dengan menggunakan penomoran dokumen yang spesifik proyek dengan pengesahan dan Manajemen Representatif K3.

\section{Pemantauan dan Evaluasi Kinerja K3}

1. Pemeriksaan, pengujian dan pengukuran

Prosedur pemeriksan, pengujian dan pengukuran secara umum meliputi :

1) Catatan pemeriksaan, pengujian dan pengukuran

Seluruh catatan K3 akan diidentifikasi dan dipelihara, disimpan dalam jangka waktu tertentu. Catatan yang telah disimpan dalam jangka waktu tertentu akan dimusnahkan. Disposisi catatan K3 dilakukan sesuai dengan peruntukan untuk menjaga keserasian, sebagaimana telah diidentifikasi dan diatur oleh Manajemen Respentatif K3.

2) Peralatan dan metode pengujian

Manajemen Representatif K3 bertanggung jawab untuk kalibrasi dan membuat daftar alat kalibrasi yang berisi status kalibrasi. Kalibrasi dapat dilakukan pihak internal atau pihak eksternal yang terakreditasi atau direkomendasi pemerintah atau rekomendasi pemasok alat.

3) Tindakan perbaikan

Seluruh pegawai PT Japfa Comfeed Indonesia Tbk Unit Cirebon bertanggung jawab untuk melaporkan ketidaksesuaian K3 ataupun potensi ketidaksesuaian kepada Manajemen Representatif K3 untuk dievaluasi dan diambil tindakan yang perlu dilaksanakan. Jika menurut Manajemen Representatif K3 hal tersebut merupakan ketidaksesuaian maka akan muncul laporan ketidaksesuaian yang akan diperhatikan dan diposisikan dan diverifikasi hasil tindak lanjutnya untuk memenuhi persyaratan yang telah ditentukan.

Penyelidikan akan dilakukan untuk setiap kecelakaan, nearmiss - accident oleh supervisor bersama dengan Manajemen Representatif K3 untuk kemudian dievaluasi dan dilaporkan kepada Direksi. Setiap tindakan perbaikan dan pencegahan yang diambil akan mempertimbangkan hirarki pengendalian risiko.

4) Penyelidikan

Seluruh pekerja PT Japfa Comfeed Indonesia Tbk Unit Cirebon dan subkontraktor harus melaporkan kecelakaan. Penyelidikan kecelakaan dilakukan untuk setiap kecelakaan, nearmiss - accident yang dilakukan oleh supervisor bersama-sama dengan Manajemen Representatif K3. Hasil penyelidikan tersebut dievaluasi oleh P2K3 dan dilaporkan ke Direksi PT Japfa Comfeed Indonesia Tbk Unit Cirebon untuk kemudian dilakukan tindakan koreksi dan pencegahan agar kecelakaan atau nearmiss - accident tidak terulang lagi.

2. Audit Sistem Manajemen Keselamatan dan Kesehatan Kerja

Audit Sistem Manajemen Keselamatan dan Kesehatan Kerja dilaksanakan minimum dua kali setahun yang dilaksanakan oleh auditor yang memiliki kriteria tertentu. 
Manajemen Representatif K3 akan melaporkan hasil audit Sistem Manajemen Keselamatan dan Kesehatan Kerja dalam rapat tinjauan Manajemen.

\section{PEMBAHASAN}

\section{Penerapan Penetapan Kebijakan K3}

Dari hasil penelitian diperoleh bahwa secara umum penerapan penetapan Kebijakan K3 di PT Japfa Comfeed Indonesia Tbk Unit Cirebon hampir semua kriteria terpenuhi, namun ada beberapa kriteria yang belum terpenuhi sebagai berikut:

1. Penetapan kebijakan K3 belum dijelaskan dan disebarluaskan kepada tamu, kontraktor, pemasok dan pelanggan sedangkan berdasarkan PP No. 50 tahun 2012 lampiran 1 menjelaskan bahwa Penetapan kebijakan K3 harus dijelaskan dan disebarluaskan kepada seluruh pekerja/buruh, tamu, kontraktor, pemasok dan pelanggan. Hal ini terjadi kemungkinan karena masih kurangnya sumber daya manusia dan waktu untuk menjelaskan dan menyebarluaskan kebijakan K3 tersebut.

2. Perusahaan belum menempatkan organisasi K3 pada posisi yang dapat menentukan keputusan perusahaan sedangkan berdasarkan PP No.50 tahun 2012 lampiran 1 menjelaskan bahwa pengusaha/pengurus menempatkan organisasi K3 pada posisi yang dapat menentukan keputusan perusahaan. Ketua P2K3 dipilih oleh kepala unit yaitu ketua bagian teknik, ketua P2K3 bukan kepala unit itu terjadi kemungkinan karena satu orang memegang satu tanggung jawab. Bila ketua P2K3 kepala unit mungkin organisasi K3 bisa menjadi penentu keputusan perusahaan.

3. Perusahaan belum melakukan penilaian kinerja dan tindak lanjut pelaksanaan K3 sedangkan berdasarkan PP No.50 tahun 2012 lampiran 1 menjelaskan bahwa pengurus atau pengusaha melakukan penilaian kinerja dan tindak lanjut pelaksanaan K3. Hal ini kemungkinan karena kurangnya sumber daya manusia.

Menurut Dinas Tenaga Kerja dan Transmigrasi Propinsi Jawa Barat Kebijakan K3 disusun dengan mempertimbangkan kinerja K3 sebelumnya, sehingga kebijakan K3 dapat menjadi pedoman dan peningkatan berkelanjutan. Kinerja K3 secara berkala harus dievaluasi melalui kajian manajemen. Dengan demikian, kebijakan K3 juga bersifat dinamis dan harus disempurnakan secara berkala. Perusahaan seharusnya melakukan penilaian kinerja dan tindak lanjut pelaksanaan K3 agar SMK3 berhasil diterapkan dan dikembangkan. ${ }^{8}$

4. Belum diadakan peninjauan ulang secara teratur sedangkan berdasarkan PP No.50 tahun 2012 lampiran 1 menjelaskan bahwa ketentuan tersebut diadakan peninjauan ulang secara teratur. Hal ini kemungkinan karena tindak lanjut belum dilakukan maka tinjauan ulang juga belum dilakukan.

\section{Penerapan Perencanaan K3}

Dari hasil penelitian diperoleh bahwa secara umum penerapan perencanaan K3 di PT Japfa Comfeed Indonesia Tbk Unit Cirebon hampir semua kriteria terpenuhi, namun ada beberapa kriteria yang belum terpenuhi sebagai berikut:

1. Peraturan perundang-undangan dan persyaratan lain belum disosialisasikan kepada seluruh pekerja/buruh sedangkan berdasarkan PP No.50 tahun 2012 lampiran 1 menjelaskan bahwa peraturan perundang-undangan dan persyaratan lain ditetapkan, dipelihara, diinventarisasi dan diidentifikasi oleh perusahaan disosialisasikan kepada seluruh pekerja/buruh. Hal ini kemungkinan karena perusahaan belum menerapkan peraturan perundangan dan persyaratan lainnya serta kurangnya sumber daya manusia untuk mensosialisasikannya.

2. Rencana K3 belum ditinjau kembali secara teratur sesuai dengan perkembangan sedangkan berdasarkan PP No.50 tahun 2012 lampiran 1 menjelaskan bahwa rencana 
K3 yang disusun oleh perusahaan memuat tujuan dan sasaran yang telah ditetapkan ditinjau kembali secara teratur sesuai dengan perkembangan. Hal ini kemungkinan keterbatasan sumber daya manusia sehingga terjadi double job.

Menurut Dinas Tenaga Kerja dan Transmigrasi Propinsi Jawa Barat Tujuan dan sasaran yang telah ditetapkan seharusnya ditinjau kembali secara teratur sesuai dengan perkembangan. Tujuan dan sasaran harus secara rutin ditinjau ulang dan direvisi berdasarkan kinerja yang dihasilkan dengan mengkonsultasikan bersama personil-personil di tempat kerja, profesional dan ahli dibidang K3 perusahaan asuransi dan orang atau kelompok lain. ${ }^{8}$

3. Perusahaan belum menetapkan indikator pencapaian sedangkan berdasarkan PP No.50 tahun 2012 lampiran 1 menjelaskan bahwa perusahaan menetapkan indikator pencapaian ditentukan dengan parameter yang dapat diukur sebagai dasar penilaian kinerja K3 yang sekaligus merupakan informasi mengenai keberhasilan pencapaian tujuan penerapan K3. Hal ini kemungkinan karena rencana tidak ditinjau ulang sehingga perusahaan belum menentukan indikator pencapaian.

Menurut Dinas Tenaga Kerja dan Transmigrasi Propinsi Jawa Barat pada saat tujuan dan sasaran ditetapkan, organisasi harus mempertimbangkan untuk menyusun indikator yang akan digunakan dalam pengukuran kinerja K3. Indikator tersebut dapat memberikan informasi mengenai manajemen K3nya serta sistem operasionalnya. ${ }^{8}$

4. Sistem pertanggung jawaban ditetapkan dalam pencapaian tujuan dan sasaran namun belum diterapkan sedangkan berdasarkan PP No.50 tahun 2012 lampiran 1 menjelaskan bahwa sistem pertanggung jawaban ditetapkan dalam pencapaian tujuan dan sasaran sesuai dengan fungsi dan tingkat manajemen perusahaan yang bersangkutan. Hal ini kemungkinan karena peninjauan ulang rencana K3 dan indikator pencapaian belum dilakukan sehingga belum dilaksanakan sistem pertanggungjawabannya.

Menurut Dinas Tenaga Kerja dan Transmigrasi Propinsi Jawa Barat Sistem pertanggung jawaban harus ditetapkan dalam pencapaian tujuan dan sasaran sesuai dengan fungsi dan tingkat manajemen perusahaan yang bersangkutan untuk menjamin perencanaan tersebut dapat dilaksanakan. Peningkatan K3 akan efektif apabila semua pihak dalam perusahaan didorong untuk berperan serta dalam penerapan dan pengembangan SMK3, dan memiliki budaya perusahaan yang mendukung dan memberikan kontribusi bagi SMK3. ${ }^{8}$

\section{Pelaksanaan Rencana K3}

Dari hasil penelitian diperoleh bahwa secara umum penerapan pelaksanaan rencana K3 di PT Japfa Comfeed Indonesia Tbk Unit Cirebon hampir semua kriteria terpenuhi, namun ada beberapa kriteria yang belum terpenuhi sebagai berikut:

1. Perusahaan menunjuk, mendokumentasikan dan belum mengkomunikasikan tanggung jawab dan tanggung gugat dibidang K3 sedangkan berdasarkan PP No.50 tahun 2012 pasal 10 lampiran 1 menjelaskan bahwa perusahaan menunjuk, mendokumentasikan dan mengkomunikasikan tanggung jawab dan tanggung gugat dibidang K3.

Hal ini kemungkinan karena kurangnya sumber daya manusia untuk mensosialisasikan tanggungjawab K3.

Menurut Dinas Tenaga Kerja dan Transmigrasi Propinsi Jawa Barat Dalam penyediaan sumber daya manusia, bentuk tanggung jawab dan tanggung gugat dalam pelaksanaan K3 yang harus dilakukan perusahaan dengan cara menunjuk, mendokumentasikan dan mengkomunikasikan tanggung jawab dan tanggung gugat dibidang K3 untuk menjamin efektifnya pengembangan dan pelaksanaan SMK3. ${ }^{8}$ 
2. Perusahaan belum mempunyai prosedur untuk memantau dan mengkomunikasikan setiap perubahan tanggung jawab dan tanggung gugat yang berpengaruh terhadap sistem dan program K3 sedangkan berdasarkan PP No.50 tahun 2012 lampiran 1 menjelaskan bahwa Perusahaan mempunyai prosedur untuk memantau dan mengkomunikasikan setiap perubahan tanggung jawab dan tanggung gugat yang berpengaruh terhadap sistem dan program K3. Hal ini kemungkinan karena perusahaan tidak fokus pada unit K3 sehingga perusahaan belum mempunyai prosedur untuk memantau dan mengkomunikasikan setiap perubahan tanggung jawab dan tanggung gugat.

3. Perusahaan mengalokasikan anggaran untuk pelaksanaan K3 belum secara menyeluruh sedangkan berdasarkan PP No.50 tahun 2012 lampiran 1 menjelaskan bahwa perusahaan mengalokasikan anggaran untuk pelaksanaan K3 secara menyeluruh. Belum semua anggaran teralokasi secara menyeluruh hal ini kemungkinan karena keterbatasan anggaran, anggaran dibuat bila ada kebutuhan mendadak namun ada beberapa anggaran dialokasikan rutin seperti masker dan sarung tangan.

4. Prosedur pelaporan eksternal yang ditetapkan belum menangani pelaporan yang dipersyaratkan peraturan perundang-undangan dan pelaporan kepada pemegang saham atau pihak lain yang terkait sedangkan berdasarkan PP No.50 tahun 2012 lampiran 1 menjelaskan bahwa prosedur pelaporan eksternal yang ditetapkan untuk menangani pelaporan yang dipersyaratkan peraturan perundang-undangan dan pelaporan kepada pemegang saham atau pihak lain yang terkait. Perusahaan belum mempunyai prosedur pelaporan informasi tetapi perusahaan tetap melakukan pelaporan kepada pihak pemegang saham/ pihak terkait.

Menurut Dinas Tenaga Kerja dan Transmigrasi Propinsi Jawa Barat Prosedur pelaporan informasi yang terkait harus ditetapkan untuk menjamin bahwa pelaporan yang tepat waktu dan memantau pelaksanaan SMK3 sehingga kinerjanya dapat ditingkatkan. ${ }^{8}$

\section{Pemantauan dan Evaluasi Kinerja K3}

Penerapan Pemantauan dan Evaluasi Kinerja K3 dikategorikan memuaskan, dari 10 kriteria sudah terpenuhi semuanya. Berdasarkan PP No.50 tahun 2012 pasal 14 tentang pemantauan dan evaluasi kinerja K3. Pemantauan dan evaluasi kinerja K3 dilaksanakan diperusahaan meliputi :

1. Pemeriksaan, pengujian dan pengukuran

PT. Japfa Comfeed Indonesia Tbk Unit Cirebon melaksanakan pemantauan dan pengukuran karakteristik kunci dari operasi dan kegiatan yang dapat menimbulkan risiko. Pemantauan meliputi pemantauan fisik, kimia, biologis, radiasi, psikologi. Manajemen Representatif K3 bertanggung jawab untuk mengidentifikasi karakteristik kunci yang harus dipantau dan diukur melalui inspeksi K3, dan setiap kegiatan yang dilaksanakan PT. Japfa Comfeed Indonesia Tbk Unit Cirebon. PT. Japfa Comfeed Indonesia Tbk Unit Cirebon mengadakan pemeriksaaan kesehatan kerja secara rutin pertahun. Pemeriksaan Kesehatan ini berlaku untuk semua tenaga kerja di PT. Japfa Comfeed Indonesia Tbk Unit Cirebon. Pengukuran sarana operasi dan alat ukur dilakukan oleh pihak eksternal. Alat pengukuran yang digunakan adalah alat yang telah terkalibrasi.

2. Audit internal SMK3

Audit internal SMK3 harus dilakukan secara berkala untuk mengetahui keefektifan penerapan SMK3. Audit Sistem Manajemen K3 dilaksanakan minimum dua kali setahun yang dilaksanakan oleh auditor yang memiliki kriteria tertentu. Manajemen 
Representatif K3 akan melaporkan hasil audit Sistem Manajemen K3 dalam tinjauan Manajemen.

\section{SIMPULAN}

1. Penetapan Kebijakan K3 di PT Japfa Comfeed Indonesia Tbk Unit Cirebon secara keseluruhan hampir semuanya terpenuhi, namun ada beberapa kriteria yang belum terpenuhi seperti: 1) penetapan kebijakan K3 belum dijelaskan dan disebarluaskan kepada tamu, kontraktor, pemasok dan pelanggan, 2) organisasi K3 belum ditempatkan pada posisi yang dapat menentukan keputusan perusahaan, 3) penilaian kinerja dan tindak lanjut pelaksanaan K3 belum dilakukan, 4) belum diadakan peninjauan ulang secara teratur.

2. Penerapan perencanaan K3 di PT Japfa Comfeed Indonesia Tbk Unit Cirebon secara keseluruhan hampir semuanya terpenuhi, namun ada beberapa kriteria yang belum terpenuhi seperti: 1) peraturan perundang-undangan dan persyaratan lain belum disosialisasikan kepada seluruh pekerja/buruh, 2) rencana K3 yang disusun belum memuat tujuan dan sasaran, 3) belum menetapkan indikator pencapaian, 4) sistem pertanggung jawaban ditetapkan namun belum diterapkan.

3. Penerapan Pelaksanaan Rencana K3 di PT Japfa Comfeed Indonesia Tbk Unit Cirebon secara keseluruhan hampir semuanya terpenuhi, namun ada beberapa kriteria yang belum terpenuhi seperti: 1) perusahaan belum mengkomunikasikan tanggung jawab K3, 2) perusahaan belum mempunyai prosedur, 3) Perusahaan belum mengalokasikan semua anggaran untuk pelaksanaan K3 secara menyeluruh, 4) belum ditetapkan prosedur pelaporan eksternal.

4. Penerapan Pemantauan dan Evaluasi Kinerja K3 di PT Japfa Comfeed Indonesia Tbk Unit Cirebon secara keseluruhan sudah terpenuhi semua.

\section{SARAN}

1. Bagi PT Japfa Comfeed Indonesia Tbk Unit Cirebon

1) Perusahaan agar memperbaiki kriteria yang belum terpenuhi antara lain:

(1) Pada Penetapan Kebijakan K3

- Kebijakan K3 agar dijelaskan dan disebarluaskan kepada tamu, kontraktor, pemasok dan pelanggan

- Perusahaan agar menempatkan organisasi K3 pada posisi yang dapat menentukan keputusan perusahaan

- Perusahaan agar melakukanakan penilaian terhadap kinerja K3

- Peninjauan ulang agar dilakukan secara teratur

(2) Pada Perencanaan K3

- Peraturan perundang-undangan dan persyaratan lain yang ada di perusahaan agar disosialisasikan kepada seluruh pekerja/buruh

- Perusahaan agar menetapkan tujuan dan sasaran dalam rencana K3

- Perusahaan agar menetapkan indikator pencapaian

- Sistem pertanggung jawaban di perusahaan agar diterapkan

(3) Pada Pelaksanaan Rencana K3

- Perusahaan agar mengkomunikasikan tanggung jawab dan tanggung gugat K3

- Perusahaan agar membuat prosedur untuk memantau dan mengkomunikasikan setiap perubahan tanggung jawab dan tanggung gugat yang berpengaruh terhadap sistem dan program K3

- Anggaran untuk pelaksanaan K3 agar dialokasikan secara menyeluruh

- Perusahaan agar menetetapkan prosedur pelaporan eksternal 
2) Perusahaan agar menambah tenaga kerja khususnya ahli $\mathrm{K} 3$ untuk mensosialisasikan dan menjalankan SMK3.

2. Bagi Tenaga Kerja PT Japfa Comfeed Indonesia Tbk Unit Cirebon

Menaati peraturan dan kebijakan K3, dan menerapkan K3 dalam melakukan kegiatannya di perusahaan.

\section{DAFTAR PUSTAKA}

1. Produk Domestik Bruto (GDP). [di akses tanggal 16 Maret 2016]. Diunduh dari: http://www.ilo.org

2. Alrasyid H. Analisis kecelakaan kerja, [di akses tanggal 16 maret 2016]. Diunduh dari : http//www.academia.edu

3. Anonim. Kecelakaan kerja di Indonesia masih tinggi. [di akses tanggal 15 Mei 2016]. Diunduh dari: http://www.berita satu.com

4. Dinas Tenaga Kerja dan Transmigrasi Propinsi Jawa Barat. Peraturan Perundangan dan Pedoman Teknis SMK3. Disnakertrans : Cirebon; 2010

5. Ramli, Soehatman. Sistem Manajemen Keselamatan dan Kesehatan Kerja OHSAS 18001. Jakarta: Dian Rakyat; 2010.

6. Sucipto, Cecep Dani. Keselamatan dan kesehatan kerja. Yogyakarta: Gosyen Publishing;2014

7. Departemen Tenaga Kerja dan Transmigrasi R.I. Modul SMK3 dan Audit SMK3. Jakarta: Depnakertrans; 2014

8. Anonim. Undang-undang ketenagakerjaan. Bandung: Fokus Media;2014

9. Biografi PT Japfa Comfeed Indonesia Tbk. [di akses tanggal 19 Maret 2016]. Diunduh dari : http://profil.merdeka.com

10. Rahimah Azmi D . Penerapan Sistem Manajemen Keselamatan dan Kesehatan Kerja Oleh P2K3 untuk Meminimalkan Kecelakaan Kerja di PT Wijaya Karya Beton Medan Tahun 2008. [di akses tanggal 21 Agustus 2014]. Diunduh dari:http://www.repository.usu.ac.id

11. Anonim. Manual SMK3 PT Japfa Comfeed Indonesia Tbk. Unit Cirebon. Cirebon: PT Japfa Comffed Indonesia Tbk; 2015

12. Anonim. Laporan Audit Sistem Manajemen Keselamatan dan Kesehatan Kerja (SMK3) di PT Japfa Comfeed Indonesia Tbk Unit Cirebon. Cirebon: PT Japfa Comfeed Indonesia Tbk; 2016

13. Notoatmodjo,soekijo. Metodologi penelitian kesehatan. Jakarta:Rineka Cipta;2010

14. Sugiyono. Metodologi penelitian kuantitatif kualitatif dan R\&D. Bandung: Alfabeta;2014

15. Zainuddin Ali. Metode penelitian hukum. Sinar Grafika:Jakarta ;2009 